\title{
An Empirical Approach toward the SLCF reduction targets in Asia for the Mid-term Climate Change Mitigation
}

HAJIME AKIMOTO ( $\square$ akimoto.hajime@neis.go.jp )

National Institute for Environmental Studies https://orcid.org/0000-0001-5553-717X

Tatsuya Nagashima

National Institute for Environmental Studies

Hiroshi Tanimoto

National Institute for Environmental Studies

Zbigniew Klimont

International Institute for Applied System Analysis

Markus Amann

International Institute for Applied System Analysis

Research article

Keywords: SLCF, Asian emission control, CH4, NOx, NMVOC

Posted Date: April 6th, 2020

DOI: https://doi.org/10.21203/rs.3.rs-20669/v1

License: (9) This work is licensed under a Creative Commons Attribution 4.0 International License.

Read Full License 


\section{An Empirical Approach toward the SLCF reduction targets in Asia}

\section{2 for the Mid-term Climate Change Mitigation}

3 Hajime Akimoto ${ }^{1}$

4 Corresponding author

5 Email: akimoto.hajime@nies.go.jp

6

7 Tatsuya Nagashima ${ }^{1}$

$8 \quad$ Email: nagashima.tatsuya@nies.go.jp

9

10 Hiroshi Tanimoto ${ }^{13}$

11 Email: tanimoto@nies.go.jp

13 Zbigniew Klimont ${ }^{2}$

14 Email: klimont@iiasa.ac.at

16 Markus Amann ${ }^{2}$

17 Email: amann@iiasa.ac.at

18

19 (Institutional address)

$20{ }^{1}$ National Institute for Environmental Studies, 16-2 Onogawa, Tsukuba Ibaraki 305-8506, 
Japan

$22{ }^{2}$ International Institute for Applied Systems Analysis, Schlossplatz 1, A-2361 Laxenburg,

23 Austria

Although importance of co-control of SLCFs together with the emission reduction of $\mathrm{CO}_{2}$ has attracted much attention for the mid-term climate change mitigation, their contribution to radiative forcing (RF) are rather complex, and chemical-climate model analysis for the future scenario tends to give black box for the contribution of each species. In order to deliver a more straightforward message on the effect of the reduction of SLCFs to policymakers, we propose "top-down" reduction targets of $\mathrm{CH}_{4}$ and tropospheric $\mathrm{O}_{3}$ in reference to the historical levels of their RF. Although the RF increase due to the increasing

$34 \mathrm{CO}_{2}$ concentration is inevitable in mid-term future (ca. $0.80 \mathrm{~W} \mathrm{~m}^{-2}$ in 2040), the $\mathrm{RF}$ of $\mathrm{CH}_{4}$ and $\mathrm{O}_{3}$ is expected to decrease from 0.48 to $0.41,0.34,0.27$, and $0.22 \mathrm{~W} \mathrm{~m}^{-2}$, and from 0.40 to $0.29,0.23,0.19$, and $0.15 \mathrm{~W} \mathrm{~m}^{-2}$, respectively, if their atmospheric concentrations decrease from the level of 2010 to those of 1980, 1970, 1960 and 1950, according to the IPCC 2013 database. Consequently, the sum of $-\Delta \mathrm{RF}_{\mathrm{x}}\left(\mathrm{CH}_{4}\right)$ and $-\Delta \mathrm{RF}_{\mathrm{x}}\left(\mathrm{O}_{3}\right)$ (the difference of RF between the target year of $\mathrm{x}$ and 2010 as the base year) are $0.18,0.31,0.42$ and 0.51 
$\mathrm{W} \mathrm{m} \mathrm{m}^{-2}$ in $1980,1970,1960$ and 1950, respectively. This indicates that the increase of $\Delta \mathrm{RF}_{2040}\left(\mathrm{CO}_{2}\right)$ can be compensated by of 23 to $64 \%$, and the policy target can be selected from the combination of different target years for $\mathrm{CH}_{4}$ and $\mathrm{O}_{3}$. With these global reduction ratio the necessary reductions in $\mathrm{CH}_{4}, \mathrm{NO}_{x}$, and $\mathrm{NMVOC}$ in Asia was estimated and compared with the GAINS model-based cost-beneficial reduction amount proposed by the Solution Report prepared under UN Environment Asia pacific Office. The comparison suggests that the reduction of $\mathrm{O}_{3}$ to the 1970 level is promising if the emissions of $\mathrm{NO}_{\mathrm{x}}$ and NMVOC from other parts of the world are reduced coherently, but further efforts would be

Keywords

SLCF, Asian emission control, $\mathrm{CH}_{4}, \mathrm{NO}_{x}, \mathrm{NMVOC}$ necessary for the reduction of $\mathrm{CH}_{4}$ emissions to realize the 1970 concentration level.

\section{Introduction}


rather well understood that co-controlling the main climate forcer, carbon monoxide $\left(\mathrm{CO}_{2}\right)$ and

59 air pollutants $\left(\mathrm{PM}_{2.5}, \mathrm{SO}_{2}, \mathrm{NO}_{\mathrm{x}}\right.$, and $\left.\mathrm{NMVOC}\right)$ simultaneously results in co-benefits of

60 mitigating climate change and human health impacts with less costs as compared to controlling

61 them separately (Sivertsen and Bartonova, 2010; Thambiran and Diab, 2011; Winiwarter and

62 Klimont, 2011; Yang and Teng, 2018), the need for controlling selected air pollutants as climate

63 forcers for climate change control has not been well-received by the public and policymakers,

64 even though the importance of co-controlling SLCPs in climate mitigation policy has been

65 asserted (Shindell et al., 2012; Shoemaker et al., 2013; Rogelj et al., 2014).

It is generally agreed that Black Carbon $(\mathrm{BC})$, Methane $\left(\mathrm{CH}_{4}\right)$, Tropospheric Ozone $\left(\mathrm{O}_{3}\right)$, and Hydrofluorocarbons (HFCs) are major SLCFs to be targeted with respect to reduction of their mixing ratios in the atmosphere by the UNEP (United Nations Environment Protection) and the CCAC (Climate and Clean Air Coalition) (UNEP, 2011a, b; CCAC, 2014). However, the problem for policymakers arises from the ambiguity of which species should be controlled with higher priority and how much each SLCF should be controlled. One of the reasons for the complexity is ascribed to the interrelationship between SLCFs and their precursors. It has been well established that emission reduction of $\mathrm{NO}_{\mathrm{x}}$ and NMVOC is necessary for the control of regional ozone (Finlayson-Pitts and Pitts, 2000; Akimoto, 2016), and that the reduction of $\mathrm{CH}_{4}$ 
Meanwhile, discussions have been made that the reduction of $\mathrm{NO}_{\mathrm{x}}$ emissions causes a decrease

in atmospheric $\mathrm{OH}$ and leads to an increase in the atmospheric lifetime and mixing ratio of $\mathrm{CH}_{4}$,

which has an adverse effect on climate change (Fuglestvedt et al., 1999; Karlsdóttir and Isaksen, 2000). This may be the reason for excluding the control of $\mathrm{O}_{3}$ by reducing $\mathrm{NO}_{\mathrm{x}}$ in the $\mathrm{CCAC}$ report (CCAC, 2017). However, our previous study (Akimoto et al., 2015) revealed that the cocontrol of $\mathrm{NO}_{\mathrm{x}}$ together with NMVOC and $\mathrm{CO}$ does not decrease much of the $\mathrm{OH}$ and only gives a nearly neutral effect on the change in $\mathrm{CH}_{4}$ concentrations.

The CCAC has emphasized the need for reduction of $\mathrm{BC}$ together with $\mathrm{CH}_{4}$ and $\mathrm{HFCs}$ (CCAC, 2014). However, a recent paper by Takemura and Suzuki (2019) reported that chemistry-climate modeling results only showed weak global warming mitigation by reducing $\mathrm{BC}$ emissions, since the sensitivity of the TOA (top of the atmosphere)-RF (radiative forcing) of $\mathrm{BC}$ on the surface temperature is minimal. Also, BC is emitted together with other "white" aerosols and the total climate impact of the reduction of $\mathrm{BC}$ emissions is uncertain, particularly when "indirect effects" are included in the climate change evaluation (e.g. Aamaas et al., 2018). Another reason for ambiguity for policymakers is that the quantitative contribution of the control of each SLCP for climate change mitigation has not been clear according to previous discussions. The effectiveness of SLCF co-control for climate change has been discussed and scenarios for preventing global surface temperature rise were proposed for the aggregated 
94 change of RF of SLCFs by using chemistry-climate models (Shindell et al., 2012; Smith, and

95 Mizrahi, 2013; Rogelj et al., 2014). While all of these model analyses are important as a

96 scientific guideline to seek the best scenario for the co-control of SLCFs, they are not

97 straightforward enough for policymakers to set effective control measures for individual SLCFs.

98 In order to give a more straightforward message to policymakers, it would be preferable to

99 make the reduction target for each SLCF visible with an evaluation of the RF value. In this

100 paper, we propose to show the reduction targets of $\mathrm{CH}_{4}$ and $\mathrm{O}_{3}$ by an "empirical top-down"

101 approach based on historical data. $\mathrm{CH}_{4}$ and $\mathrm{O}_{3}$ were selected since linearity between $\mathrm{RF}$ and

102 surface temperature change can be presumed for these gaseous SLCFs to allow an additive

103 discussion of $\mathrm{RF}$ of $\mathrm{CO}_{2}$. In the present study, we adopted an approach in which the historical

104 atmospheric mixing ratios of $\mathrm{CH}_{4}$ and $\mathrm{O}_{3}$ are referred to as having been related to the lower

105 anthropogenic emissions of $\mathrm{CH}_{4}, \mathrm{NO}_{x}$, and $\mathrm{NMVOC}$ in the past, and we envisioned the targeted

106 emission reduction of these species in Asia . The results were compared with a recent proposal

107 of 25 cost-effective measures for the emission control of anthropogenic air pollutants in Asia in

1082030 by the WHO air quality guidelines and the sustainable development goals (SDGs) (UNE,

109 2018) using the GAINS (Greenhouse Gas and Air Pollution Interactions and Synergies) model

110 of IIASA (International Institute of Applied Systems Analysis) (Amann et al., 2011). 


\section{Methods/Experimental}

112 Increase of RF due to the increase of $\mathrm{CO}_{2}$ in 2040 and possible compensation by

\section{3 the decrease of $\mathrm{CH}_{4}$ and $\mathrm{O}_{3}$}

114 Four future scenarios of GHG emissions until 2150 have been evaluated in the Fifth Assessment

115 Report (AR5) of the IPCC (2013). Each scenario, named RCP8.5, RCP6.0, RCP4.5, and

$116 \mathrm{RCP} 2.6$, corresponds to an $\mathrm{RF}$ at $8.5,6.0,4.5$, and $2.6 \mathrm{~W} \mathrm{~m}^{-2}$ in 2100 , respectively, with

117 reference to the preindustrial era. Figure 1 shows the past and future atmospheric mixing ratios

118 of $\mathrm{CO}_{2}$ according to these four scenarios (Meinshausen et al, 2011; Myhre and Shindell, 2013).

119 It is clearly shown in Fig. 1 that the atmospheric mixing ratios of $\mathrm{CO}_{2}$ of the RCP6.0, 4.5, and

1202.6 (called RCP3PD in the figure) scenarios will not differ significantly until 2040 when they

121 reach $450 \pm 10 \mathrm{ppm}$ (Myhre and Shindell, 2013). Based on these projections, the RF due to $\mathrm{CO}_{2}$

122 is estimated to reach $\sim 2.6 \mathrm{~W} \mathrm{~m}^{-2}$ in all of these three scenarios in 2040 . Since the $\mathrm{RF}$ of $\mathrm{CO}_{2}$ is

$1231.82 \pm 0.2 \mathrm{~W} \mathrm{~m}^{-2}$ in 2011 (Myhre and Shindell, 2013), the increase of RF due to the increase of

$124 \mathrm{CO}_{2}$ from 2011 to 2040 is expected to be ca. $0.8 \mathrm{~W} \mathrm{~m}^{-2}$. In order to mitigate the enhanced near-

125 and mid-term climate change due to the increase of $\mathrm{CO}_{2}$, the increase of $\mathrm{RF}$ has to be

126 compensated by a reduction in the RF of SLCFs.

127 Historical change of the RF of Methane and Ozone

128 The global mean atmospheric mixing ratio of $\mathrm{CH}_{4}$ has been increasing from the preindustrial 
129 value of $\sim 750 \mathrm{ppb}$ in 1750 to the present value of $1803 \pm 2 \mathrm{ppb}$ in 2011 (Myhre and Shindell,

130 2013). Figure 2 shows the historical increase of $\mathrm{CH}_{4}$ mixing ratios in the Antarctic (orange line)

131 compiled by Ghosh et al. (2015) together with the $\mathrm{RF}$ of $\mathrm{CH}_{4}$ given by the IPCC AR5 (blue

132 line) (Myhre and Shindell, 2013). The growth rate of the $\mathrm{CH}_{4}$ concentration is moderate (5.1

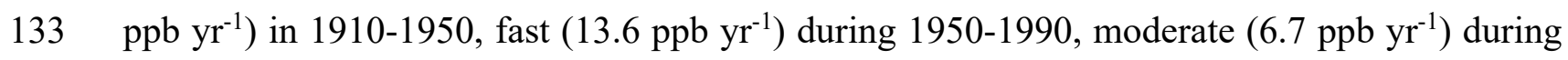

134 the 1990s, and near steady to moderate after 2000 (Ghosh et al., 2015). The increase of RF is

135 not linear but nearly proportional to the global averaged concentration for a shorter period of

136 time. As shown in Fig. 2, the $\mathrm{RF}$ of $\mathrm{CH}_{4}$ in 2010 referenced to the preindustrial era of 1750 is

$1370.48 \pm 0.20 \mathrm{~W} \mathrm{~m}^{-2}$.

138 Figure 3 depicts the historical increase of the model-calculated global mean tropospheric $\mathrm{O}_{3}$

139 column (orange line) together with the RF given by Myhre and Shindell (2013) in the IPCC

$140 \mathrm{AR} 5$ (blue line). Since the $\mathrm{RF}$ of $\mathrm{O}_{3}$ reflects the change in the mean tropospheric burden rather

141 than the mixing ratio in the surface layer, the global mean tropospheric $\mathrm{O}_{3}$ column represented

142 in Dobson unit (DU) by Skeie et al. (2011) is quoted here. The global mean tropospheric column

143 has increased from 2.3 DU in 1910 to $11.4 \mathrm{DU}$ in 2010. The continuous increase of RF is in

144 parallel with the increase of the global mean tropospheric $\mathrm{O}_{3}$ column, and it accelerated in the

1451960 s and slowed down after the 1980s. The historical increase of the tropospheric burden of

$146 \mathrm{O}_{3}$ can be ascribed to the increase of anthropogenic emissions of its precursors, $\mathrm{NO}_{\mathrm{x}}, \mathrm{NMVOC}$, 
$147 \mathrm{CO}$, and $\mathrm{CH}_{4}$ (Lamarque et al., 2005; Stevenson et al., 2013; Hoesly et al., 2018). According to

148 the IPCC AR5 (Myhre and Shindell, 2013), the radiative forcing of tropospheric $\mathrm{O}_{3}$ in 2010

149 referenced to the preindustrial era is $0.40 \pm 0.20 \mathrm{~W} \mathrm{~m}^{-2}$ mainly based on the ACCMIP model

150 intercomparison study (Stevenson et al., 2013). Compared to the RF of well-mixed GHGs such

151 as $\mathrm{CH}_{4}$, the $\mathrm{RF}$ of tropospheric $\mathrm{O}_{3}$ has a large uncertainty up to $\pm 50 \%$ (5 to $95 \%$ confidence),

152 which reflects a large inter-model spread because of a large latitudinal, longitudinal, and

153 altitudinal variability reflecting the spatial and temporal non-uniformity of emission sources of

154 its precursors, $\mathrm{NO}_{\mathrm{x}}, \mathrm{VOC}$, and $\mathrm{CO}$. Another large uncertainty arises from the lack of knowledge

155 about the pre-industrial level of tropospheric $\mathrm{O}_{3}$ that provides the reference value of RF. The

156 reported observed values of ground-level $\mathrm{O}_{3}$ in the late 19th and early 20th century have been

157 reevaluated and revised to be approximately $10 \mathrm{ppbv}$ and at the most $15 \mathrm{ppbv}$ (Volz and Kley,

158 1988; Marenco et al., 1994; Cooper et al., 2014) in the mid-latitude in the northern hemisphere

159 where data is available from. However, the model-simulated mixing ratio of the pre-industrial

160 level of $\mathrm{O}_{3}$ is typically 20 ppbv (Mickley and Jacob, 2001; Lamarque et al., 2005; Young et

161 al., 2018), substantially higher than the reported observed values, which tend to give a smaller

162 industrial $\mathrm{RF}$ of $\mathrm{O}_{3}$.

163 It should be noted that the $\mathrm{RFs}$ of $\mathrm{CH}_{4}$ and tropospheric $\mathrm{O}_{3}$ in 2011 relative to 1750 are $0.48 \pm$

1640.05 and $0.40 \pm 0.20 \mathrm{~W} \mathrm{~m}^{-2}$, respectively, (total $0.88 \mathrm{~W} \mathrm{~m}^{-2}$ ), which is comparable to the increase 
165 of RF due to the increase of $\mathrm{CO}_{2}$ from 2011 to 2040 (Myhre and Shindell, 2013).

\section{Results}

\section{Target setting of the Reduction of Global $\mathrm{CH}_{4}$ and $\mathrm{O}_{3}$ to a Historical Year}

169 Based on Figs. 2 and 3, Table 1 cites the $\mathrm{RF}_{\mathrm{x}}$ and $\square \mathrm{RF}_{\mathrm{x}}$ of $\mathrm{CH}_{4}$ and $\mathrm{O}_{3}$ for a specified year, $\mathrm{x}$

$170 \quad\left(\mathrm{x}=2010,1980,1970,1960\right.$ and 1950), where $\square \mathrm{RF}_{\mathrm{x}}=\mathrm{RF}_{\mathrm{x}}-\mathrm{RF}_{2010}$ for the year $\mathrm{x}$. As shown in

171 Table 1, the radiative forcing of $\mathrm{CH}_{4}$ decreases from 0.48 to $0.41,0.34,0.27$, and $0.22 \mathrm{~W} \mathrm{~m}^{-2}$,

172 and that of $\mathrm{O}_{3}$ from 0.40 to $0.29,0.23,0.19$, and $0.15 \mathrm{~W} \mathrm{~m}^{-2}$ if their mixing ratios decrease from

173 the level of 2010 to the levels of 1980, 1970, 1960 and 1950, respectively. Accordingly, -

$174 \square \mathrm{RF}_{\mathrm{x}}\left(\mathrm{CH}_{4}\right)$ and $-\square \mathrm{RF}_{\mathrm{x}}\left(\mathrm{O}_{3}\right)$ increase to $0.07,0.14,0.21$, and 0.26 , and $0.11,0.17,0.21$, and 0.25 ,

175 for $1980,1970,1960$, and 1950, respectively. Therefore, the sums of $-\square \mathrm{RF}_{\mathrm{x}}\left(\mathrm{CH}_{4}\right)$ and -

$176 \square \mathrm{RF}_{\mathrm{x}}\left(\mathrm{O}_{3}\right)$ are $0.18,0.31,0.42$, and $0.51 \mathrm{~W} \mathrm{~m}^{-2}$ in $1980,1970,1960$ and 1950 , respectively,

177 which means that if the atmospheric burdens of $\mathrm{CH}_{4}$ and $\mathrm{O}_{3}$ are decreased to the levels of 1980,

1781970,1960 , and 1950 , the increase of $\square \mathrm{RF}_{2040}\left(\mathrm{CO}_{2}\right)\left(0.80 \mathrm{~W} \mathrm{~m}^{-2}\right)$ can be compensated by $23 \%$,

$17939 \%, 53 \%$, and $64 \%$, respectively.

180 To set the target year to which the level of $\mathrm{CH}_{4}$ and $\mathrm{O}_{3}$ should be reduced is rather arbitrary

181 at this stage, but one can get a clear idea of how much of the total RF can be reduced by setting

182 the target of emission reduction of $\mathrm{CH}_{4}$ and $\mathrm{NO}_{x} / \mathrm{NMVOC}$ as $\mathrm{O}_{3}$ precursors. For example, if 
183 both $\mathrm{CH}_{4}$ and $\mathrm{O}_{3}$ can be reduced to the levels of 1970 and $1960,39 \%$ and $53 \%$ of the increase

184 in $\mathrm{RF}$ by $\mathrm{CO}_{2}$ can be suppressed by in 2040. If the target of $\mathrm{CH}_{4}$ reduction is the 1970 level and

185 that of $\mathrm{O}_{3}$ is 1960 considering more difficulty of anthropogenic $\mathrm{CH}_{4}$ emissions as will be

186 discussed later, $-\square \mathrm{RF}_{\mathrm{x}}\left(\mathrm{CH}_{4}\right)-\square \mathrm{RF}_{\mathrm{x}}\left(\mathrm{O}_{3}\right)$ becomes $0.35 \mathrm{~W} \mathrm{~m} \mathrm{~m}^{-2}$, or the compensation rate

187 becomes $44 \%$. In the present study, the targeted year has been set rather arbitrarily to 1970 to

188 see how feasible the compensation of ca. $40 \%$ of the RF increase by $\mathrm{CO}_{2}$ is in 2040.

Targeted Reduction of Global and Asian Emissions of $\mathrm{CH}_{4}, \mathrm{NO}_{\mathrm{x}}$, and $\mathrm{NMVOC}$

190 Global total and Asia/Pacific historical anthropogenic sectoral emissions of $\mathrm{CH}_{4}, \mathrm{NO}_{\mathrm{x}}$, and

191 NMVOC were obtained from the Community Emissions Data System (CEDS) by Hoesly et al.

192 (2018). Here, Asia/Pacific is grouped to cover East, Southeast, South and West Asia, and

193 Oceania and the Pacific Islands. In this database, sectoral emission data are available every ten

194 years. Table 2 shows the anthropogenic emissions of $\mathrm{CH}_{4}, \mathrm{NO}_{\mathrm{x}}$, and $\mathrm{NMVOC}$ globally and in

195 the Asia/Pacific region in $1970\left(\mathrm{E}_{1970}\right)$ and $2010\left(\mathrm{E}_{2010}\right)$. Also shown are the reduction ratios (1-

$\left.196 \mathrm{E}_{1970} / \mathrm{E}_{2010}\right)$ of each species, which are the necessary fractions of the emissions when we aim to

197 reduce their emissions from the 2010 to the 1970 level.

198 The data in Table 2 show that the share of anthropogenic emissions of $\mathrm{CH}_{4}, \mathrm{NO}_{\mathrm{x}}$, and

199 NMVOCs in the Asia/Pacific region is $32 \%, 18 \%$, and $27 \%$, respectively, of the global total in

2001970 , and they increased to $47 \%, 48 \%$ and $53 \%$, respectively, nearly $50 \%$ of the global 
emissions in 2010.

202 It has been pointed out that the Asian emissions of $\mathrm{NO}_{\mathrm{x}}$ and $\mathrm{CO}_{2}$ are nearly half of the global 203 emissions in 2008 (EANET/SAC/TFRC, 2015). The rapid growth of Asian emissions since 2041970 was most clearly seen for $\mathrm{NO}_{\mathrm{x}}$ compared with the emissions in Europe and North America 205 (Akimoto, 2003). Thus, the contribution of the Asian emissions of air pollutants and climate 206 forcers was minor in the global emissions in 1970, but Asia was the major emitter in the world 207 in 2010 and emissions have been increasing further until recently.

208 This situation strongly suggests that controlling SLCFs and $\mathrm{CO}_{2}$ emissions in Asia is 209 particularly important for climate change mitigation, and setting a clear reduction target for

210 SLCFs is urgent. However, if we set 1970 as the target year to which level the anthropogenic

211 global emissions of $\mathrm{CH}_{4}, \mathrm{NO}_{x}$, and NMVOC should be reduced, it would not be feasible for

212 Asian emissions in 2040 to the level of 1970 of its own. Instead, we take the global reduction

213 ratio as a guideline for the emission controlled level of $\mathrm{CH}_{4}, \mathrm{NO}_{\mathrm{x}}$, and $\mathrm{NMVOC}$ in 2040, 214 applying also to Asia. Although the statistical emission data of "Asia/Pacific" in Table 2 by 215 Hoesly et al. (2018) includes the Pacific area, this group's emissions are largely dominated by 216 the emissions from Asia in the base year of 2010, therefore, we use the term "Asia" for the 217 reduction estimates in the discussion hereafter.

218 In order to reduce the global anthropogenic emissions of $\mathrm{CH}_{4}$ from the level of 2010 (357 
$\left.219 \mathrm{Tg} \mathrm{CH}_{4} \mathrm{yr}^{-1}\right)$ to that of $1970\left(233 \mathrm{Tg} \mathrm{CH}_{4} \mathrm{yr}^{-1}\right)$, total emissions in 2010 have to be reduced by

$22035 \%$, as shown in Table 2. If this reduction ratio is applied to Asia, the target reduction of Asian

221 emissions in 2040 becomes $110 \mathrm{Tg} \mathrm{CH}_{4}$ with a decrease of $59 \mathrm{Tg} \mathrm{CH}_{4}$.

222 Similarly, in order to reduce the global anthropogenic emissions of $\mathrm{NO}_{\mathrm{x}}$ from the emission

223 level of $141 \mathrm{Tg} \mathrm{NO}_{2} \mathrm{yr}^{-1}$ in 2010 to $79 \mathrm{Tg} \mathrm{NO}_{2} \mathrm{yr}^{-1}$ in 1970 , emissions have to be reduced by

$22444 \%$ by 2040 . When the global reduction ratio, 0.44 , is applied to the Asian emissions, the target

225 reduction in 2040 becomes $38 \mathrm{Tg} \mathrm{NO}_{2} \mathrm{yr}^{-1}$ rather than the actual $\mathrm{NO}_{\mathrm{x}}$ emission of $14 \mathrm{Tg} \mathrm{NO}_{2}$

$226 \mathrm{yr}^{-1}$ in the Asia/Pacific in 1970.

227 Anthropogenic emissions of NMVOC should be reduced by the global reduction ratio of $22 \%$,

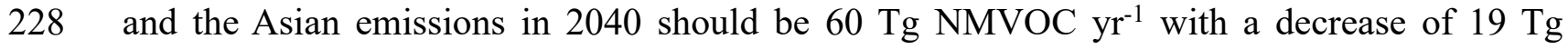

229 NMVOC $\mathrm{yr}^{-1}$. The increase of global and Asian anthropogenic NMVOC emissions from 1970

230 to 2010 is by a factor of 1.3 and 2.5 , respectively, as compared to the ratios of 1.8 and 4.9 for

$231 \mathrm{NO}_{\mathrm{x}}$. Thus, the anthropogenic emissions of $\mathrm{NO}_{\mathrm{x}}$ have increased much more rapidly than

232 NMVOC emissions in Asia. It should be noted that the emissions from biomass burning are not

233 included in these emission data and are not discussed in the present study.

234 Comparison with the Reduction Scenario in the Cost-Benefit Measures Based

235 on the GAINS Model

236 "Air Pollution in the Asia Pacific: Science-Based Solutions (Solution Report)" prepared by 
237 the CCAC and APCAP (Asia Pacific Clean Air Partnership)/Science Panel has recently been

238 published by the UN Environment, Asia Pacific Office (UNE, 2018). In this report, 25 measures

239 to reduce emissions of air pollutants and $\mathrm{CH}_{4}$ in Asia in 2030 in a cost-effective way have been

240 proposed based on the GAINS model (Amann et al., 2011) as actionable options for

241 policymakers. They aim at tackling air pollution to achieve the WHO guideline values for $\mathrm{PM}_{2.5}$

242 and $\mathrm{O}_{3}$ concentrations, and near-term climate change by a third of a degree Celsius by 2050 .

243 Although the publication did not report any reduced amount of $\mathrm{RF}$ for climate forcers $\mathrm{CH}_{4}$ and

$244 \mathrm{O}_{3}$, it would be interesting to compare the cost-benefit reduction of $\mathrm{CH}_{4}, \mathrm{NO}_{\mathrm{x}}$, and $\mathrm{NMVOC}$ in

245 Asia proposed in this publication with the top-down approach to reduce the $\mathrm{RF}$ of $\mathrm{CH}_{4}$ and $\mathrm{O}_{3}$

246 to the level of 1970 deduced in the present study.

247 Table 3 compares the Asian emissions of $\mathrm{CH}_{4}, \mathrm{NO}_{x}$, and NMVOC in 2010 and 2040 (after

248 subtracting the targeted reduction) so far discussed, to those in the baseline scenario in 2010

249 and 2030 with proposed measures deduced in the Solution Report (UNE, 2018). Since the

250 absolute amount of emissions of each species in the reference year of 2010 are substantially

251 different between the studies due to either different coverage of sources and/or uncertainties in

252 the emission factors, here we discuss the reduction ratios between the projected year and the

253 reference year. It is interesting to note that the proposed reduction of $\mathrm{NO}_{\mathrm{x}}$ and $\mathrm{NMVOC}$ in the

254 Solution Report is more stringent than the targeted top-down RF reduction based on global 
average reduction ratios and even closer to the reduction ratio based on Asian emissions in 1970 .

256 These results imply that the emission control to fulfill the targeted reduction is most feasible

257 for $\mathrm{NO}_{\mathrm{x}}$ and $\mathrm{NMVOC}$, and the $\mathrm{RF}$ of $\mathrm{O}_{3}$ could be reduced to $50 \%$ of the present value if the

258 emissions of NOx and NMVOC from other parts of the world could be reduced coherently. In

259 contrast, the reduction ratio of $\mathrm{CH}_{4}$ proposed in the Solution Report (0.26) is substantially

260 smaller than the targeted reduction ratio (0.35) in this study, and the reduction of $\mathrm{CH}_{4}$ would

261 need further effort.

262 Feasibility of Reduction of Anthropogenic Emissions of $\mathrm{CH}_{4}, \mathrm{NOx}$, and NMVOC

\section{3 in Asia by Sectors}

264 In order to get an insight into the feasibility of the targeted emission reduction of $\mathrm{CH}_{4}, \mathrm{NO}_{\mathrm{x}}$,

265 and NMVOC in Asia, a comparison of targeted reduction with a single global reduction factor

266 and the Solution Report proposal has been made by sector. Livestock farming (enteric

267 fermentation from cattle and sheep), coal production (discharge from coal mining), gas and oil

268 production (leaks from oil and natural gas production, transmission and use), followed by waste

269 treatment and rice paddies are the predominant sources of anthropogenic $\mathrm{CH}_{4}$ in Asia as of 2010.

270 As for $\mathrm{NO}_{\mathrm{x}}$, power plants and industries are the dominant sources followed by transport in Asia.

271 Major sources of anthropogenic emissions of NMVOC are distributed to coal, gas and oil

272 production, transport, residential sector, and solvent use. 
273 Table 4 compares the reduction of anthropogenic emissions of $\mathrm{CH}_{4}, \mathrm{NO}_{\mathrm{x}}$, and $\mathrm{NMVOC}$ in Asia

274 by source sector between the top-down targeted approach and the cost-effective model approach.

275 Table 4 gives some insight into the feasibility of the reduction of SLCFs by sector proposed in

276 the Solution Report (UNE, 2018). For example, as for the reduction of anthropogenic $\mathrm{CH}_{4}$

277 emissions, the emission reductions of coal production and gas and oil production are well

278 regulated according to the Solution Report. The much higher emission reduction of waste

279 treatment in the proposed measures implies that the control of this sector is expected to be cost-

280 effectively promising. In contrast, emission control of $\mathrm{CH}_{4}$ from livestock farming is much less

281 feasible even though this source contributes significantly to the $\mathrm{CH}_{4}$ emissions in Asia.

282 As for $\mathrm{NO}_{x}$, The relative importance of the potential reduction of fixed sources (power

283 plant/industries and waste treatment $)\left(17 \mathrm{Tg} \mathrm{NO}_{\mathrm{x}} \mathrm{yr}^{-1}\right)$ is about two times higher than those of

284 the mobile sources (transport) $\left(9 \mathrm{Tg} \mathrm{NO}_{\mathrm{x}} \mathrm{yr}^{-1}\right)$ in Asia. The contribution of power plants in Asia

285 in 2010 is much higher and that of transport is much lower than the contribution of these sectors

286 to the global emissions. As for the reduction of anthropogenic sources of $\mathrm{NO}_{\mathrm{x}}$ in Asia, road

287 transport emissions are the most feasible to reduce by measures according to the Solution

288 Report (UNE, 2018) as shown in Table 4. Also, it is suggested that the $\mathrm{NO}_{\mathrm{x}}$ emissions from

289 waste treatment can also be controlled cost-efficiently.

290 In Asia, coal, oil and gas production, transport, and residential are the top three contributors of 
291 the NMVOC emissions, followed by solvent use. It can be noted that the emissions from

292 transport increased drastically from $9 \%$ in 1970 to $22 \%$ in 2010 in contrast to a slightly

293 decreasing global trend from $23 \%$ to $20 \%$ during these years. Furthermore, a substantial

294 reduction of NMVOC emissions from transport, solvent use, residential and waste treatment is

295 feasible. The overall reduction of NMVOC more than targeted by the top-down approach is

296 promising.

297

298 Discussion

299 Since the UNEP/WMO (2011) and UNEP (2011a) raised the importance of the co-control of

300 SLCFs together with the emission reduction of $\mathrm{CO}_{2}$ for the alleviation of mid- and long-term

301 climate change and air pollution mitigation simultaneously, many studies have been conducted

302 using chemistry-climate models for the evaluation of the reduction effect of $\mathrm{CH}_{4}, \mathrm{O}_{3}$, and $\mathrm{HFC}$

303 and BC as SLCFs (Shindell et al., 2012; Smith and Mizrahi, 2013; Rogelj et al., 2014; Akimoto

304 et al., 2015). Among these, $\mathrm{CH}_{4}, \mathrm{O}_{3}$, and $\mathrm{HFC}$ are gaseous climate forcers and their RFs are

305 thought to be used as a measure of global heating of near-surface temperature additively to that

306 of $\mathrm{CO}_{2}$ to evaluate their contribution to climate change. In addition, it has recently been reported

307 that the reduction of $\mathrm{BC}$, a particulate climate forcer, is less effective as global warming

308 mitigation, since the sensitivity of the RF of BC on surface temperature is minimal, which is 
attributed to the positive radiative budget of $\mathrm{BC}$ being largely compensated for by rapid

310 atmospheric adjustment (Takemura and Suzuki, 2019). Although a reduction in the emission of

311 BC is definitely advantageous from the point of human health and it also helps climate change

312 mitigation by reducing the absorption of solar radiation by BC-deposited snow/ice, its effect on

313 global warming is not additive to other gaseous SLCFs. For this reason, we give priority to the

314 gaseous SLCFs, $\mathrm{CH}_{4}$ and $\mathrm{O}_{3}$, to be reduced, and have discussed in this paper.

315 Particularly in Asia, the incentives for controlling climate change and air pollution vary

316 significantly by country (Akimoto et al, 2015), so that it is more appropriate to evaluate the

317 effect of emission reduction on RF by each species, since the reduction of each SLCF has

318 different implication from an air pollution control point of view. In reality, however, there are

319 complicated interactions among gaseous SLCFs and their precursors, e.g. the reduction of $\mathrm{NO}_{\mathrm{x}}$

320 emissions for the reduction of tropospheric $\mathrm{O}_{3}$ causes a decrease in atmospheric $\mathrm{OH}$

321 concentrations and leads to an increase in $\mathrm{CH}_{4}$ concentrations, while a decrease in $\mathrm{CH}_{4}$ will

322 reduce $\mathrm{O}_{3}$, etc. (Fuglestvedt et al., 1999; Karlsdóttir and Isaksen, 2000). For these reasons, most

323 of the discussion for asserting the importance of SLCF co-control for the alleviation of surface

324 temperature rise have demonstrated the overall effect of co-control of typically $\mathrm{BC}$ and $\mathrm{CH}_{4}$

325 excluding the discussion of the reduction of $\mathrm{O}_{3}$ by $\mathrm{NO}_{\mathrm{x}}$ and $\mathrm{NMVOC}$ based on chemical-climate

326 models (Shindell et al., 2012; Shoemaker et al., 2013; Rogelj et al., 2014). 

the $\mathrm{RF}$ of tropospheric $\mathrm{O}_{3}$ is the second highest next to that of $\mathrm{CH}_{4}$ and it has more relevance to air quality and human health, which would give more incentive to policymakers to focus on reducing it. This paper proposed a top-down view of RF reduction of the empirical approach

331 based on the assumption that if the emissions can be reduced to some historical level, it would

332 ensure the reduction of concentrations to the same historical level, provided other conditions

333 do not change much. The advantage of this approach is that it gives a relative importance of the

334 targeted reduction of each SLCF which is thought to be useful for policymakers. On the other

335 hand, the disadvantage of the empirical approach may include that atmospheric interactions

336 between different species during the course of emission reduction before the targeted goal is

337 attained cannot be considered, emission reduction is evaluated only by the total amount ignoring

338 the change in spatial distribution, and climate conditions in 2040 will be different from those in

339 the past, etc. On the other hand, the uncertainties in the modeling approach have also been

340 pointed out and the fact that the results vary by model, and the effect of SLCF reduction has a

341 large uncertainty when climate change due to aerosols is taken into account (Smith and Mizrahi,

342 2013). Thus, both the empirical and the model approach have advantages and disadvantages

343 and they should be considered complementary.

344 Among the gaseous SLCFs, the RF of HCFC is ca. $0.1 \mathrm{~W} \mathrm{~m}^{-2}$ as of 2010 (Shoemaker et al., 
2013). The complete phase-out of HCFCs will add another $\square \square \mathrm{RF}_{\mathrm{x}}(\mathrm{HCFC})=0.1 \mathrm{~W} \mathrm{~m}^{-2}$ to the

346 total of $\square \square \mathrm{RF}_{\mathrm{x}}\left(\mathrm{CH}_{4}\right) \square \square \mathrm{RF}_{\mathrm{x}}\left(\mathrm{O}_{3}\right)$, i.e., to 0.31 and $0.42 \mathrm{~W} \mathrm{~m}^{-2}$ (Table 1) resulting in 0.41 and

$3470.52 \mathrm{~W} \mathrm{~m}^{-2}$ at the 1970 and 1960 level, respectively. Then, the compensation ratios for the 0.8

$348 \mathrm{~W} \mathrm{~m}{ }^{-2}$ increase of $\mathrm{RF}_{\mathrm{x}}\left(\mathrm{CO}_{2}\right)$ in 2040 will be $51 \%$ and $65 \%$, which is more promising for

349 alleviating climate change than by reducing $\mathrm{CH}_{4}$ and $\mathrm{O}_{3}$ alone.

As shown in Table 3, the reduction ratio of $\mathrm{CH}_{4}$ by the GAINS model, 0.26 , is substantially

351 lower than the 0.35 reduction required by the top-down approach using the global reduction

352 factor. Table 4 shows that the reduction of $\mathrm{CH}_{4}$ emissions is most feasible for waste treatment

353 and coal, gas and oil production, and least feasible for livestock farming. Since the contribution

354 of the emissions from livestock is the largest at both the global and Asian scale, the mitigation

355 of climate change by reducing $\mathrm{CH}_{4}$ emissions from this source will be more feasible if a new

356 technology for the reduction of livestock $\mathrm{CH}_{4}$ is developed in the future.

357 The reduction ratio of $\mathrm{NO}_{\mathrm{x}}$ and NMVOC in Asia in 2030 compared to 2010 reported in the

358 Solution Report is more than 50\% (Table 3) which is much larger than what is required by the

359 top-down approach with the global reduction ratios. This means that if the reduction presumed

360 by the GAINS model together with the coordinated reductions in other parts of the world is

361 realized, the $\mathrm{RF}$ of $\mathrm{O}_{3}$ would be expected to decrease to be much lower than $0.17 \mathrm{~W} \mathrm{~m}^{-2}$ for the

362 level of 1970 . As for the $\mathrm{NO}_{\mathrm{x}}$ control, the reduction in the power plant and industry sector is 
363 less feasible than that in the transport sector, as shown in Table 4 according to the GAINS model.

364 This suggests that the enhancement of energy transformation from fossil fuel to renewable

365 energy is highly advantageous from the point of climate change mitigation by $\mathrm{O}_{3}$ reduction in

366 addition to the $\mathrm{CO}_{2}$ reduction measures.

367 The emissions of $\mathrm{CO}$ have been known to contribute to the production of tropospheric $\mathrm{O}_{3}$

368 (Lamarque et al., 2005). The global emission of CO has already decreased since 2000, and the

369 increase in Asian emissions has also almost stopped (Dentener et al., 2005), which would lead

370 to a decrease in regional and global $\mathrm{O}_{3}$ together with a reduction of $\mathrm{NO}_{\mathrm{x}}$ and NMVOC.

\section{Conclusions}

373 A guideline of the SLCP co-control in Asia for climate change mitigation in the mid-term future

374 has been proposed by a "top-down" empirical approach based on historical concentrations and

$375 \mathrm{RF}$ of $\mathrm{CH}_{4}$ and tropospheric $\mathrm{O}_{3}$. As an example, if the global concentrations of $\mathrm{CH}_{4}$ and

376 tropospheric $\mathrm{O}_{3}$ can be decreased from the level of 2010 to the historical levels of 1970 and

377 1960, their RFs will decrease from 0.48 to 0.34 and $0.27 \mathrm{~W} \mathrm{~m}^{-2}$, and from 0.40 to 0.23 and 0.19

$378 \mathrm{~W} \mathrm{~m}{ }^{-2}$, respectively. The sum of $\square \square \mathrm{RF}_{\mathrm{x}}\left(\mathrm{CH}_{4}\right)$ and $\square \square \mathrm{RF}_{\mathrm{x}}\left(\mathrm{O}_{3}\right)$ are 0.31 and $0.42 \mathrm{~W} \mathrm{~m}^{-2}$ for the 379 reduction to the 1970 and 1960 levels, respectively, which can compensate for 39\% and 53\% 380 of the increase of RF by the increase of $\mathrm{CO}_{2}$ in 2040. 
cost-beneficial reduction amount in 2030 proposed in the Solution Report prepared under the

suggested that the reduction of $\mathrm{O}_{3}$ to the 1970 level is promising, while further efforts would

387 be necessary for the reduction of anthropogenic $\mathrm{CH}_{4}$ emissions to reach the 1970 concentration 388 level.

\section{Abbreviations}

391 CCAC: Climate and Clean Air Coalition; GAINS: Greenhouse gas and air pollution interactions

392 and synergies; HFC: Hydrofluorocarbon; IIASA: International Institute of Applied System

393 Analysis; IPCC: International Panel on Climate Change; NMVOC: Non-methane volatile

394 organic compounds; RCP: Representative Concentration Pathways; RF: Radiative forcing;

395 SDGs: Sustainable development goals; SLCF: Short-lived climate forcer; SLCP: Short-lived

396 climate pollutant; TOA; Top of the atmosphere; UNE: United Nations Environment; UNEP:

397 United Nations Environment Program; WHO: World Health Organization; WMO: World

398 Meteorological Organization 
400 Declarations

401 Availability of data and material

402 All the datasets except those of "solution report" in Table 4 are is available in each of the cited

403 references. The numerical data for the "solution report" in Table 4 is available from ZK at 404 IIASA.

405

406 Competing interests

407 The authors declare no conflict of interest.

408

$409 \quad$ Funding

410 This research was funded by the Environmental Research and Technology Development Fund

411 (S-12 and 2-1803) of the Ministry of the Environment, Japan.

412

413 Authors' contributions

414 HA analyzed the data and wrote the first draft of the paper. TN worked out the preparation of

415 numerical data of emissions and conducted discussions for the paper. HT proposed the 416 interpretation of the data and contributed to the overall discussion of the paper. ZK and MA 
417 provided the numerical data of the GAINS model output and ZK discussed the detailed

418 interpretation of the data.

419

\section{Authors' information}

421 HA, TN and HT are atmospheric chemists who have been studying on reactive gases and

422 aerosols relevant to air quality. They have recently been concerned in science and policy related

423 to the co-control of air pollution and climate change. ZK and MA have developed the GAINS

424 model for evaluating air pollutants and greenhouse gasses synergistically, and have been

425 playing a key role on the establishment of the atmospheric management policy in Europe.

426 Recently, they are interested in the mitigation of air pollution and climate change in Asia.

427

428 Acknowledgements

429 We thank Eric Zusman at IGES for his comments on the draft. We also thank Nagy Tanaka Edit

430 for the English language review.

\section{References}

433 Aamaas B., Lund MT, Myhre G, Samset BH, Stjern CW, Kallbekken S (2018) The climate impacts of

434 current black carbon and organic carbon emissions. CICERO Report 2018:08, CICERO Center for 
International Climate Research, Oslo

436 Akimoto H. (2003) Global Air Quality and Pollution. Science 302:1716-1719

437 Akimoto H (2016) Atmospheric Reaction Chemistry. Springer Japan, Tokyo

438 Akimoto H, Kurokawa J, Sudo K, Nagashima T, Takemura T, Klimont Z, Amann M, Suzuki K (2015)

439 SLCF co-control approach in East Asia: Tropospheric ozone reduction strategy by simultaneous

440 reduction of $\mathrm{NO}_{\mathrm{x}} / \mathrm{NMVOC}$ and methane. Atmos Environ 122:588-595

441 Amann M, Bertok I, Borken-Kleefeld J, Cofala J, Heyes C, Höglund-Isaksson L, Klimont Z, Nguyen B,

442 Posch M, Rafaj P, Sandler R, Schöpp W, Wagner F, Winiwarter W (2011) Cost-effective control of air

443 quality and greenhouse gases in Europe: Modelling and policy applications. Environ Model Soft

$444 \quad 26: 1489-1501$

445 CCAC (2014) Time to Act to Reduce Short-Lived Climate Pollutants, $2^{\text {nd }}$ Ed. CCAC Secretariat, Paris

446 CCAC (2017) Benefits of mitigating short-lived climate pollutants, https://www.ccacoalition.org/en/

447 content/benefits-mitigating-short-lived-climate-pollutants

448 Cooper OR, Parrish DD, Ziemke J, Balashov NV, Cupeiro M, Galbally IE, Gilge S, Horowitz L, Jensen

449 NR, Lamarque J-F, Naik V, Oltmans SJ, Schwab J, Shindell DT, Thompson AM, Thouret V, Wang Y,

450 Zbinden RM (2014) Global distribution and trends of tropospheric ozone: An observation-based review.

451 Elem Sci Anthrop 2. doi:10.12952/journal.elementa.000029

452 Dentener F, Stevenson D, Cofala J, Mechler R, Amann M, Bergamaschi P, Raes F, Derwent R (2005) 
453 The impact of air pollutant and methane emission controls on tropospheric ozone and radiative forcing:

454 CTM calculations for the period 1990-2030. Atmos Chem Phys 5:1731-1755

455 EANET/SAC/TFRC (2015) Review on the State of Air Pollution in East Asia, Task Force on Research

456 Coordination (TFRC), Scientific Advisory Committee (SAC), Acid Deposition Monitoring Network in

457 East Asia (EANET). http://www.eanet.asia/product/index.html

458 Finlayson-Pitts BJ, Pitts JN Jr (2000) Chemistry of the Upper and Lower Atmosphere. Academic Press

459 Fuglestvedt JS, Berntsen TK, Isaksen ISA, Mao H, Liang X-Z, Wang W-C (1999) Climatic forcing of

460 nitrogen oxides through changes in tropospheric ozone and methane; global 3D model studies. Atmos

461 Environ 33:961-977

462 Ghosh A, Patra PK, Ishijima K, Umezawa T, Ito A, Etheridge DM, Sugawara S, Kawamura K, Miller

463 JB, Dlugokencky EJ, (2015) Variations in global methane sources and sinks during 1910-2010. Atmos

464 Chem Phys 15:2595-2612

465 Hoesly RM, Smith SJ, Feng L, Klimont Z, Janssens-Maenhout G, Pitkanen T, Seibert JJ, Vu L, Andres

466 RJ, Bolt RM, Bond TC, Dawidowski L, Kholod N, Kurokawa J, Li M, Liu L, Lu Z, Moura MCP,

467 O'Rourke PR, Zhang Q (2018) Historical (1750-2014) anthropogenic emissions of reactive gases and

468 aerosols from the Community Emissions Data System (CEDS). Geosci. Model Dev 11:369-408

469 IPCC (2013) Climate Change 2013: The Physical Science Basis. Working Group I Contribution to the Fifth

470 Assessment Report of the Intergovernmental Panel on Climate Change. Cambridge University Press, 
472 Karlsdóttir S, Isaksen ISA (2000) Changing methane lifetime- Possible cause for reduced growth.

473 Geophys Res Lett 27:93-96

474 Lamarque JF, Hess P, Emmons L, Buja L, Washington W, Granier C (2005) Tropospheric ozone

475 evolution between 1890 and 1990. J Geophys Res 110:D08304. doi:10.1029/2004JD005537.

476 Marenco A, Gouget H, Nédéec P, Pagés J-P (1994) Evidence of a long-term increase in tropospheric

477 ozone from Pic du Midi data series: Consequences: Positive radiative forcing. J Geophys Res 99:16,617-

$478 \quad 16,632$

479 Meinshausen M, Smith SJ, Calvin K, Daniel JS, Kainuma MLT, Lamarque J-F, Matsumoto K, Montzka

480 SA, Raper SCB, Riahi K, Thomson A, Velders GJM, van Vuuren DPP (2011) The RCP greenhouse gas

481 concentrations and their extensions from 1765 to 2300. Climate Change 109:313-241

482 Mickley LJ, Jacob DJ (2001) Uncertainty in preindustrial abundances of tropospheric ozone:

483 Implications for radiative forcing calculations. J Geophys Res 106:3389-3399

484 Myhre G, Shindell D (2013) Anthropogenic and natural radiative forcing, In Climate Change 2013: The 485 Physical Science Basis. IPCC AR5 WG1, University Press, Cambridge

486 Rogelj J, Schaeffer M, Meinshausen M, Shindell DT Hare W, Klimont Z, Velders GJM, Amann M, 487 Schellnhuber $\mathrm{HJ}$ (2014) Disentangling the effects of $\mathrm{CO}_{2}$ and short-lived climate forcer mitigation, Proc 
Fowler D (2012) Simultaneously mitigating near-term climate change and improving human health and

494 Shoemaker JK, Schrag DP, Molina MJ, Ramanathan V (2013) What role for short-lived climate 495 pollutants in mitigation policy? Science 342:1323-1324

496 Sivertsen B, Bartonova A (2010) Co-Benefit and co-control studies in Norway. Chem. Ind Chem Eng 497 Quart 16:281-286

498 Skeie RB, Berntsen TK, Myhre G, Tanaka K, Kvalevåg MM, Hoyle CR (2011) Anthropogenic radiative 499 forcing time series from pre-industrial times until 2010. Atmos Chem Phys 11:11827-11857

500 Smith SJ, Mizrahi A (2013) Near-term climate mitigation by short-lived forcer., Proc Nat Acad Sci 110:

502 Stevenson DS, Young PJ, Naik V, Lamarque J-F, Shindell DT, Voulgarakis A., Skeie RB, Dalsoren SB,

503 Myhre G, T. Berntsen K, Folberth GA, Rumbold ST, Collins WJ, MacKenzie IA, Doherty RM, 504 Zeng G, van Noije TPC, Strunk A, Bergmann D, Cameron-Smith P, Plummer DA, Strode 505 SA, Horowitz L, Lee YH, Szopa SK, Sudo K, Nagashima T, Josse B, Cionni I, Righi M, et al. 506 (2013) Tropospheric ozone changes, radiative forcing and attribution to emissions in the Atmospheric 
508 Takemura T, Suzuki K. (2019) Weak global warming mitigation by reducing black carbon emissions.

509 Nature Sci. Rep 9:4419. https://doi.org/10.1038/s41598-019-41181-6.

510 Thambiran T, Diab RD (2011) Air pollution and climate change co-benefit opportunities in the road

511 transportation sector in Durban, South Africa. Atmos Environ. 45:2683-2689

512 UNE (2018) Air Pollution in Asia and the Pacific: Science-based Solutions. Climate and Clean Air

513 Coalition (CCAC) and Asia Pacific Clean Air Partnership (APCAP). UNEP, Paris

514 UNEP/WMO (2011) Integrated Assessment of Black Carbon and Tropospheric Ozone: Summary for

515 Decision Makers. http://www.unep.org/dewa/Portals/67/pdf/Black_Carbon.pdf.

516 UNEP (2011a). Near-term Climate Protection and Clean Air Benefits: Actions for Controlling Short-

517 lived Climate Forcers. UNEP, Nairobi

518 UNEP (2011b) HFCs: A Critical link in protecting climate and the ozone layer. Nairobi.

519 Volz A, Kley D (1988) Evaluation of the Montsouris series of ozone measurements made in the 520 nineteenth century, Nature 332:240 - 242

521 Winiwarter W, Klimont $\mathrm{Z}$ (2011) The role of $\mathrm{N}$-gases $\left(\mathrm{N}_{2} \mathrm{O}, \mathrm{NO}_{\mathrm{x}}, \mathrm{NH}_{3}\right)$ in cost-effective strategies to 522 reduce greenhouse gas emissions and air pollution in Europe. Curr Opin Environ Sustain 3: 438-445

523 Yang X, Teng F (2018) The air quality co-benefit of coal control strategy in China, Resourc Conserv

524 Recyc 129:373-382 
526 Tilmes S, Wild O, Zhang L, Ziemke JR, Brandt J, Delcloo A, Doherty RM, Geels C, Hegglin MI, Hu L,

527 Im U, Kumar R, Luhar A, Murray L, Plummer D, Rodriguez J, Saiz-Lopez A, Schultz MG, Woodhouse

528 MT, Zeng G, (2018) Tropospheric Ozone Assessment Report: Assessment of global-scale model

529 performance for global and regional ozone distributions, variability, and trends, Elem Sci Anthrop 6.

530 doi.org/10.1525/elementa.265

531

\section{Figure legends}

533 Figure 1. Atmospheric concentration of $\mathrm{CO}_{2}$ in the past and future according to the IPCC

534 emission scenarios RCP8.5, 6.0, 4.5, and 3PD (Peak and Decline to $3 \mathrm{~W} \mathrm{~m}^{-2}$ by 2100) (based

535 on Meinshausen et al., 2011).

536 Figure 2. Historical trend of $\mathrm{CH}_{4}$ concentrations at Antarctica (orange line) and radiative forcing of

$537 \mathrm{CH}_{4}$ (blue line) (adapted from Ghosh et al., 2015, and Myhre and Shindell, 2013, respectively).

538 Figure 3. Historical trend of Tropospheric $\mathrm{O}_{3}$ column (blue line) and radiative forcing (orange line)

539 (adapted from Skeie et al., 2011 and Myhre and Shindell, 2013, respectively). 


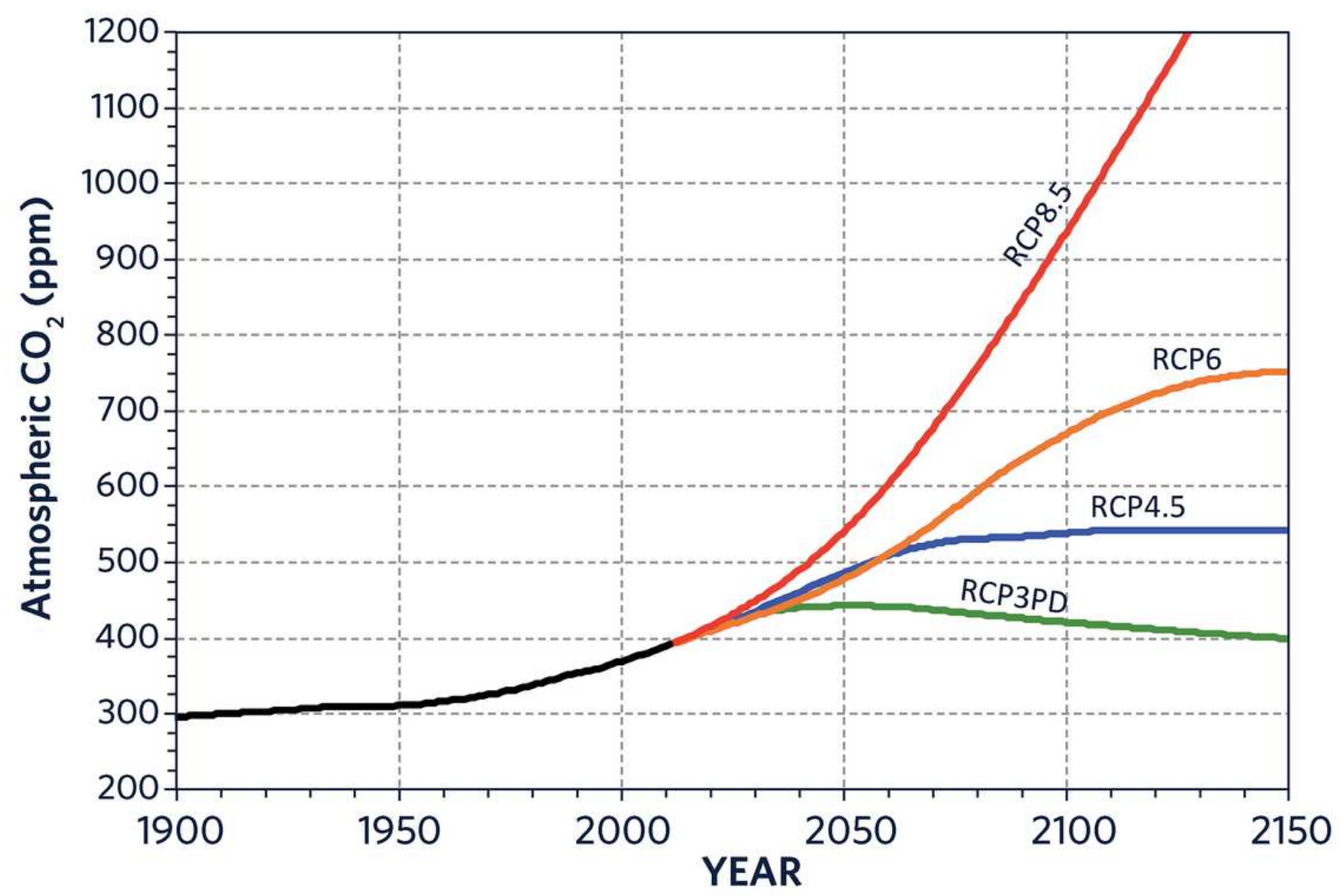

Figure 1

Atmospheric concentration of $\mathrm{CO} 2$ in the past and future according to the IPCC emission scenarios RCP8.5, 6.0, 4.5, and 3PD (Peak and Decline to 3 W m-2 by 2100) (based on Meinshausen et al., 2011).

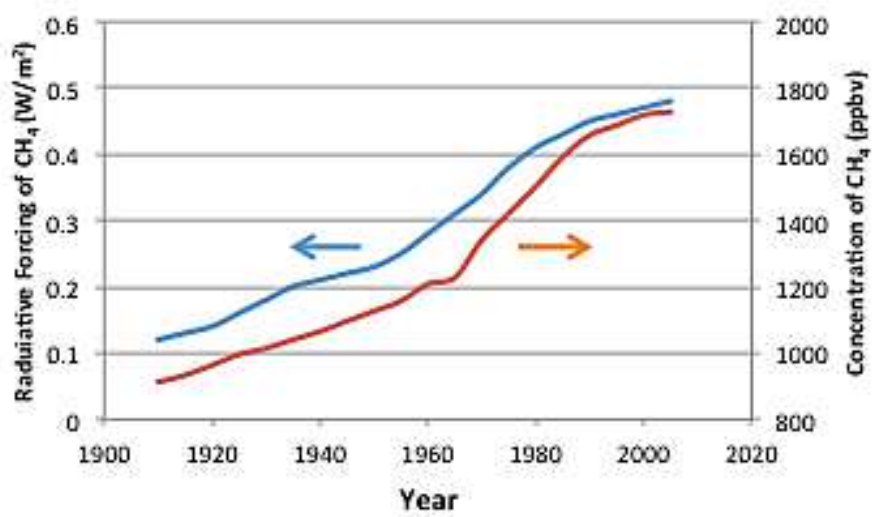

Figure 2 
Historical trend of $\mathrm{CH} 4$ concentrations at Antarctica (orange line) and radiative forcing of $\mathrm{CH} 4$ (blue line) (adapted from Ghosh et al., 2015, and Myhre and Shindell, 2013, respectively).

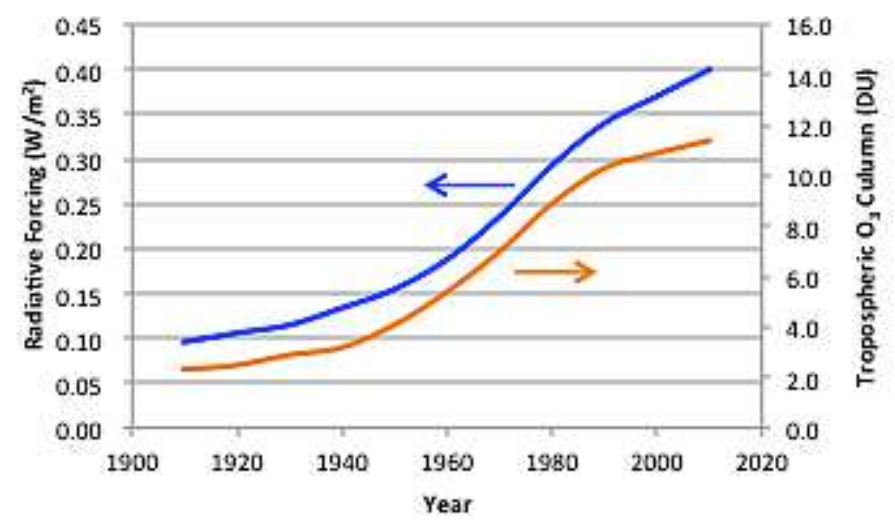

\section{Figure 3}

Historical trend of Tropospheric 03 column (blue line) and radiative forcing (orange line) (adapted from Skeie et al., 2011 and Myhre and Shindell, 2013, respectively).

\section{Supplementary Files}

This is a list of supplementary files associated with this preprint. Click to download.

- AbstractFigure.png 